\title{
Co-digestion of Olive Mill Wastewater and Swine Manure Using Up-Flow Anaerobic Sludge Blanket Reactor for Biogas Production
}

\author{
Hassan Azaizeh, Jeries Jadoun \\ Institute of Applied Research, University of Haifa, Shefa Amr, Israel \\ E-mail:hazaizeh@yahoo.com,hazaizi@gal-soc.org \\ Received December 18, 2009; revised December 29, 2009; accepted January 29, 2010
}

\begin{abstract}
Swine wastewater (SW) and olive mill wastewater (OMW) are two problematic wastes that have become major causes of health and environmental concerns. The main objective of the current work was to evaluate the efficiency of the co-digestion strategy for treatment of SW and OMW mixtures. Mesophilic batch reactors fed with mixtures of SW and OMW showed that the two adapted sludges Gadot and Prigat exhibited the best COD removal capacity and biogas production; therefore both were selected to seed up-flow anaerobic sludge blanket (UASB) continuous reactors. During 170 days of operation, both sludges Gadot and Prigat showed high biodegradation potential. The highest COD removal of $85-95 \%$ and biogas production of 0.55 $\mathrm{L} \cdot \mathrm{g}^{-1}$ COD were obtained at a mixture consisting of $33 \%$ OMW and $67 \% \mathrm{SW}$. Under these conditions, an organic load of $28,000 \mathrm{mg} \cdot \mathrm{L}^{-1} \mathrm{COD}$ was reduced to $1,500-3,500 \mathrm{mg} \cdot \mathrm{L}^{-1}$. These results strongly suggest that co-digestion technology using UASB reactors is a highly reliable and promising technology for wastewater treatment and biogas production.
\end{abstract}

Keywords: Anaerobic Co-digestion, Olive Mill Waste Effluent, Swine Manure, Biogas, Mesophilic Temperature

\section{Introduction}

The olive oil industry represents a very important agroindustrial sector in the economy of the Mediterranean region. Currently, two main milling processes are applied to obtain extra virgin olive oil: the traditional three-phase system, which is used widely in Italy, Greece, Israel and other Mediterranean countries, and the two-phase system, which is mainly used in Spain [1]. In the three-phase system, the wastes generated are olive mill wastewater (OMW) and olive mill solid wastewater, whereas with the two-phase system, only a semisolid by-product is obtained that contains both water and solid residue. The average amount of OMW produced during the milling process using the three stages process is $1.2-1.8 \mathrm{~m}^{3} \cdot \mathrm{t}^{-1} . \mathrm{In}$ the olive-growing countries of the Mediterranean area approximately 30 million $\mathrm{m}^{3}$ OMW effluents are produced as by-products per year, of which about 370,000 $\mathrm{m}^{3}$ are produced in the Middle Eastern region [2,3]. In these countries, OMW is a potential and active source of environmental pollution due to its high content of polyphenols, tannins, and lipids, which exhibit phytotoxic and antimicrobial activities [4-6], as well as a high potential to contaminate surface and ground water $[3,6,7]$. To resolve these problems several processes have been developed such as incineration, concentration by evaporation, chemical and electrochemical treatments [8-12], anaerobic treatment [13-15] or a combination of these strategies [16]. However, except for anaerobic treatment, these processes provide incomplete treatment.

Anaerobic treatment of wastes has drawn considerable attention because of the conversion of organic molecules into methane, an economically valuable biogas that can be used to generate heat and electricity [17]. The high organic load of OMW makes anaerobic treatment a very attractive treatment option for such waste. However, obtaining high anaerobic treatment efficiency of OMW has been hampered by (a) very high organic loading (biological oxygen demand (BOD) and chemical oxygen demand (COD) concentrations could reach 100 and 200 $\mathrm{g} \cdot \mathrm{L}^{-1}$, respectively) $[6,18]$, (b) high acidity, (c) low nitrogen content, and (d) the presence of compounds difficult to biodegrade, including phenolic compounds, lipids and long chain fatty acids $[2,19]$, most of which are in- 
hibitory for the sludge bacteria (primarily methanogens) responsible for the biodegradation process [2,6,20,21]. In order to overcome these problems, several pre- and post-treatment processes have been proposed. These processes include dilution [2,22], application of two different and serially connected types of anaerobic digesters, removal of phenolic compounds using sand filtration and powdered activated carbon [3], the electro-Fenton method [12], coagulation-flocculation compounds [23], or by employing an anaerobic OMW-digesting microbial consortium passively immobilized in column reactors and packed with granular activated carbon or silica beads [24], enzymatic removal [25] or microbial degradation of phenolic compounds by fungi [6,26-32] or algae [33]. Although these processes may provide a solution, their use is compromised by one or more of the following: cumbersome operation, extra expenses, lower methane productivity (due to a decrease of COD availability as in the case of dilution), production of phenolic compound derivatives during pretreatment that are more toxic than original phenolic compounds [30], and incompatibility between the level of the removal rate of phenolic compound and the level of COD reduction efficiency $(95 \%$ removal results only in a maximum of $85 \%$ COD reduction) $[3,23]$.

Anaerobic co-digestion is a cost-effective waste treatment method, in which two different types of organic wastes are mixed and treated together in a single facility [34]. The reason for using a mixture of two different wastes in the anaerobic co-digestion process lies in taking advantage of the abundance of a specific compound in one waste type to compensate for its shortage in the other waste type, and consequently increase biodegradability and methane production [34]. Using such approach, satisfactory results were obtained with several combinations of mixed agricultural wastes, for example, swine and poultry wastes [35] or energy crops and cow wastes [36]. In both cases, it was shown that co-digestion not only facilitated biodegradation of the organic compounds but also enhanced methane production.

The presence of major pathogens and antibiotics in poorly treated swine wastewater (SW) and manure [37-39] and their potential to contaminate both surface water and groundwater [40], which then can enter into the human food chain and water resources [41], raises considerable health and environmental concerns. The anaerobic codigestion approach can be used as an alternative treatment for solving environmental pollution problems from both OMW and SW. SW, with OMW as a codigestate, can be optimal for the co-digestion process. While OMW is characterized by seasonal production, high organic load, high concentrations of lipids and phenolic compounds and high acidity, SW is characterized by yearround production, low organic load, but exhibits a high concentration of nitrogen compounds and high alkalinity [42-44]. Therefore, mixing OMW with SW will not only result in dilution of the inhibitory compounds in OMW, but also the adjustment of $\mathrm{pH}$ to a neutral value and will compensate for nitrogen shortage, resulting eventually in increased biodegradability and methane production [44].

The up-flow anaerobic sludge blanket (UASB) system is one of the reactor types with high loading capacity and it differs from other reactors by the simplicity of its design [45]. Only 70-80\% in COD reduction rates and 65$75 \%$ in methane production rates has been reported for UASB systems treating OMW and SW mixes [44,46]. Optimization of the anaerobic co-digestion process for higher organic reduction and methane production rates is imperative for large-scale economic use of such technology. Therefore, the aim of this research is to increase the economic capacity of the anaerobic co-digestion process of OMW and SW in a UASB system. Since the performance of the UASB system is highly dependent on the source of the sludge, i.e., the composition of the microbial biomass responsible for biodegradation, special emphasis was put on selection of appropriate sludge source. This was done in parallel to optimization of the co-digestion process for higher reduction efficiency of the organic load while maintaining high biogas production capacity.

\section{Materials and Methods}

\subsection{Analytical Methods}

Volatile solids, total solids and BOD and COD, were determined using Standard Methods [47]. Prior COD analysis, each batch or UASB sample was centrifuged at $5000 \mathrm{rpm}$ for $10 \mathrm{~min}$. Total nitrogen and phosphate were determined using the Kjeldahl-N method (steam distillation) [47].

\subsection{Batch Experiments}

SW and OMW were collected from nearby farms in the Galilee region, Israel. OMW came from a three-phase continuous olive oil extraction process and SW was obtained from a pig farm. Preliminary results showed that an OMW: SW ratio of 1:1 (50\% of each wastewater), but not $1: 2(33 \%$ OMW and $67 \% \mathrm{SW})$, inhibited the biodegradation process. Therefore, the latter ratio was used for all subsequent batch experiments. In order to study the effect of the organic load of the OMW: SW mixture and the retention time on the performance of the batch reactors, eight different concentrations (ranging from 1050 to $20100 \mathrm{mg} \cdot \mathrm{L}^{-1}$ ) of the mixture were prepared by dilution with water (see results). To identify sludge types which are mostly adapted to co-digestion, and to be subsequently used in the UASB experiments, five different sludge sources (Sakhnin Municipal Wastewater Plant, 
Haifa Municipal Wastewater Plant, Olive Mill Wastewater Plant, Gadot Chemical Wastewater Plant, and Prigat Soft Drink Wastewater Plant) were used for inoculation of each OMW:SW concentration as follows: sterile serum flasks were filled with $250 \mathrm{~mL}$ of a given COD and inoculated with $25 \mathrm{~g}$ sludge of a different source. After mixing, the $\mathrm{pH}$ in each flask was adjusted to neutral $\mathrm{pH}$. The flasks were incubated in a water bath at $38 \pm 2^{\circ} \mathrm{C}$ for 11 days. Samples were taken several times during the incubation period (depending on the removal capacity of the sludge) to determine the COD level. In parallel, the emitted biogas was collected continuously in cylinders filled with water standing upside down in a water bath to determine the level of biogas production. For comparison, another similar set of COD concentration was prepared, in which SW was used as the sole wastewater, inoculated with the different sludge types as mentioned and tested for biodegradation and biogas production. Since none of the sludge types were able to biodegrade high COD concentrations prepared only with OMW, such experiments were excluded from the study.

\subsection{UASB Experiments}

The UASB used in this study, made of Plexiglas, was built with a double jacket. The internal diameter, external diameter and the height of the UASB system were 5.5 $\mathrm{cm}, 12 \mathrm{~cm}$, and $223 \mathrm{~cm}$, respectively. It had an active volume of 8.1 liters. The temperature in the UASB was controlled by circulating hot water from an electrically controlled heat exchanger through the external jacket of the reactors. Two UASB reactors, one seeded with Gadot sludge and the other with Prigat sludge, were operated simultaneously to test their potential in COD removal and biogas production over time. The UASB reactors were fed in the first 60 days of operation with $6 \mathrm{~L} \cdot \mathrm{d}^{-1}$ mixtures of OMW and SW, and thereafter the feed was raised up to $10 \mathrm{~L} \cdot \mathrm{d}^{-1}$. Each UASB reactor was seeded either with $500 \mathrm{~mL}$ of granular Prigat sludge or Gadot sludge, which were found to yield the best results in the previous batch experiments. The COD of the OMW was ca $140 \mathrm{~g} \cdot \mathrm{L}^{-1}$ and for SW ranged between $14-25 \mathrm{~g} \cdot \mathrm{L}^{-1}$. A starting OMW: SW ratio of 1:2 (corresponding to 5,000 $\mathrm{mg} \cdot \mathrm{L}^{-1} \mathrm{COD}$ ) was prepared from these wastes and pumped into the bottom of each reactor simultaneously using a peristaltic pump. The $\mathrm{pH}$ of the effluent mixture was around 7.0 and the average temperature was kept at $36^{\circ} \mathrm{C}$ in both reactors. The corresponding organic load rate (OLR) was calculated per day during the 170 days of operation. In the first 60 days, the feed was fixed at $6 \mathrm{~L} \cdot \mathrm{d}^{-1}$ (with $5,000 \mathrm{mg} \cdot \mathrm{L}^{-1} \mathrm{COD}$ initially and increased gradually up to $\left.28,000 \mathrm{mg} \cdot \mathrm{L}^{-1}\right)$, and thereafter it was increased to $10 \mathrm{~L} \cdot \mathrm{d}^{-1}\left(\mathrm{COD}\right.$ of $\left.25,000-28,000 \mathrm{mg} \cdot \mathrm{L}^{-1}\right)$. Influent and effluent samples were collected periodically from each UASB and analyzed for COD content, as described earlier, in order to calculate the COD removal capacity of each UASB.

\section{Results and Discussion}

\subsection{Batch Experiments}

\subsubsection{Effect of the Retention Time and Organic Load on the Performance of the Batch Reactors Seeded with Different Sludge Types}

Various dilutions of a stock mixture of OMW: SW at a ratio of 1:2 were prepared and inoculated with five different sludge types. The quantity of biomass (sludge) was maintained constant during the experiments. The biodegradation process was allowed to occur for $11 \mathrm{sub}$ sequent days. The organic load in the bioreactors seeded with Haifa sludge was reduced slightly but steadily during the whole 11 days, particularly at an initial COD above $7,550 \mathrm{mg} \cdot \mathrm{mL}^{-1}$, suggesting that a retention time of 11 days does not sustain the full degradation potential of this sludge (data not shown). The same result was also obtained for the Sakhnin sludge (data not shown). In contrast, the organic load in the bioreactors seeded with Gadot (Figure 1), Prigat (Figure 2), and OMW (data not shown) was sharply reduced within 2-4 days (depending on the initial COD), and then the COD removal rate remained constant during the subsequent days. This indicates that a retention time of 2-4 days was sufficient to

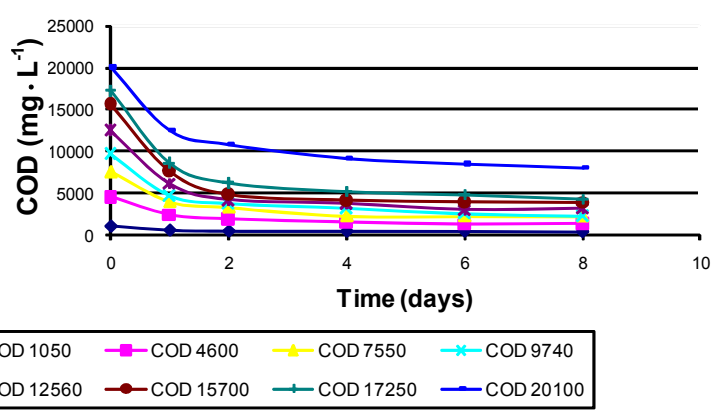

Figure 1. Reduction of COD over time in batch experiments using Gadot sludge.

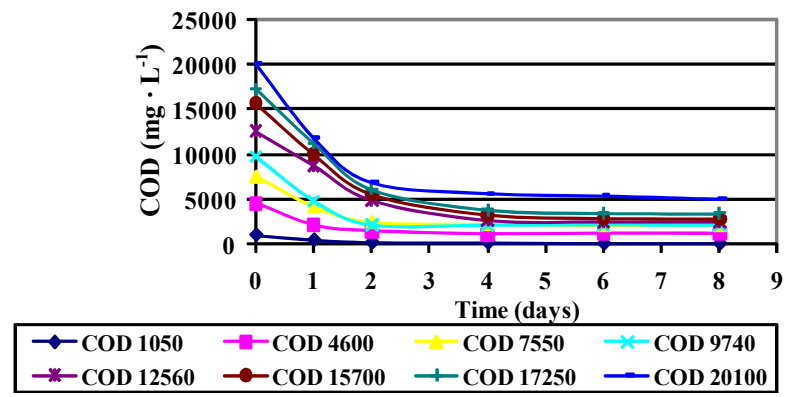

Figure 2. Reduction of COD over time in batch experiments using Prigat sludge. 
achieve maximum degradation potential of these two sludges.

\subsubsection{Effect of the Organic Load on the Co-digestion of OMW and SW using Different Sludge Types}

The COD removal rate and accumulated biogas calculated and collected on day 11 were used to evaluate the co-digestion potential of each sludge type. In the bioreactor seeded either with Haifa sludge (Figure 3) or Sakhnin sludge (data not shown), increasing the organic load (initial COD) up to $9,740 \mathrm{mg} \cdot \mathrm{mL}^{-1}$ and 12,560 $\mathrm{mg} \cdot \mathrm{mL}^{-1}$, respectively, resulted in increased biogas production and COD removal rate. However, increasing the
COD level above these values resulted in a substantial reduction in biogas accumulation and COD removal rate. This effect could be attributed to the inhibition of the co-digestion process caused by the polyphenols and tannins present in OMW, which are apparently toxic to the sludge bacteria at these high concentrations of COD. Interestingly, the behavior of bioreactors seeded with OMW, Gadot and Prigat sludges was completely different. In the bioreactors seeded with either Gadot or Prigat sludges, increasing the initial COD resulted in increased amounts of accumulated biogas, even at high COD levels reaching 17,250 $\mathrm{mg} \cdot \mathrm{mL}^{-1}$ (Figures 4 and 5). Moreover, the COD removal rate of these sludge types, particularly

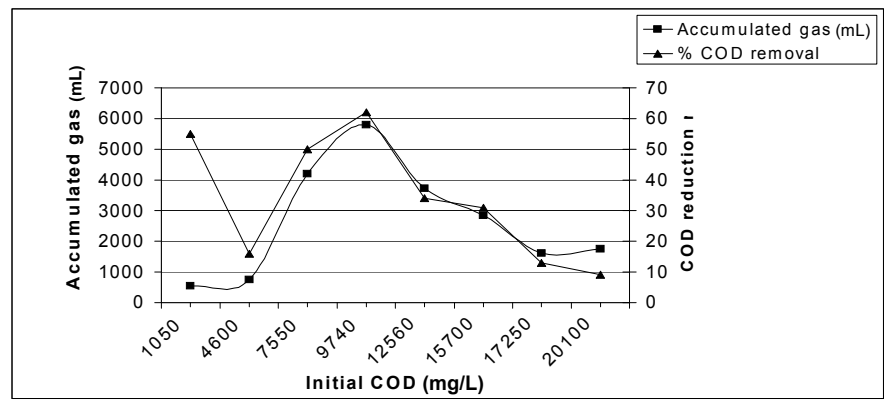

Figure 3. The effect of COD concentration on the COD reduction rate and accumulation of biogas in batch experiments using Haifa sludge.

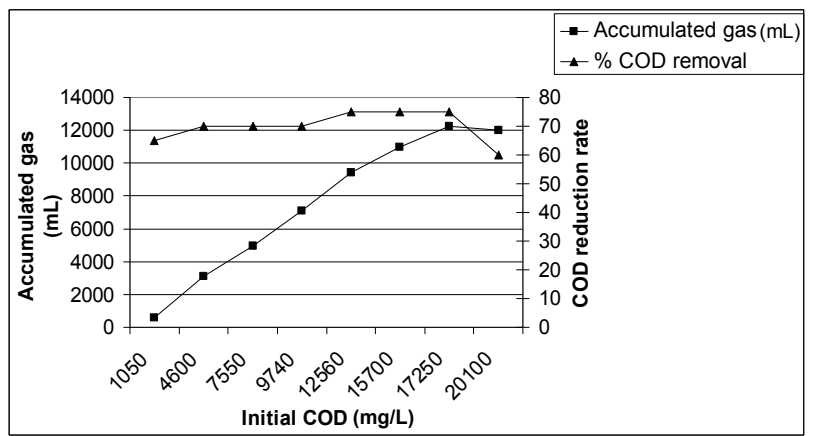

Figure 4. The effect of COD concentration on the COD reduction rate and accumulation of biogas in batch experiments using Gadot sludge.

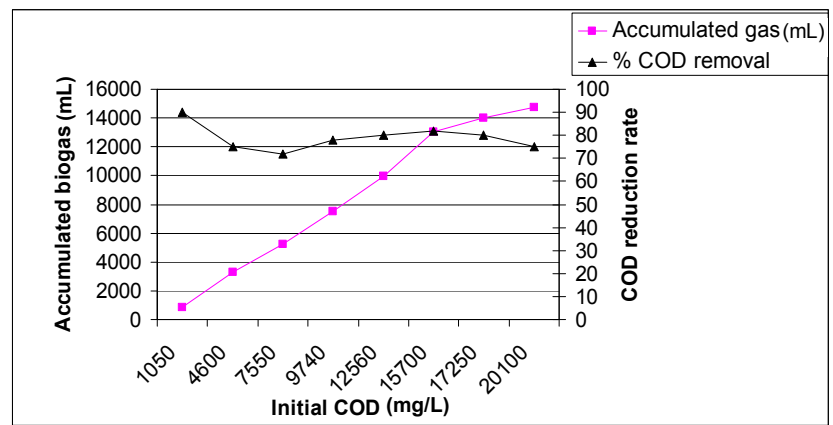

Figure 5. The effect of COD concentration on the COD reduction rate and the accumulation of biogas in batch experiments using Prigat sludge. 
the OMW (data not shown) and Prigat (Figure 5), remained almost constant irrespective of the initial COD value. In addition, both the accumulated biogas and the COD removal rates of the three sludge types were substantially higher than those obtained with the Haifa and Sakhnin sludge types at any COD value tested. Only at concentrations higher than $17,250 \mathrm{mg} \cdot \mathrm{mL}^{-1}$, the toxic effect of polyphenols in OMW, where the co-digestion potential of these sludge bacteria was affected. (Figures 4 and 5). These results clearly indicate that OMW, Prigat and Gadot sludge types obtained from agricultural waste plants are more compatible for the co-digestion process of the OMW:SW mixtures, probably due to the higher tolerance of the sludge bacteria to the phenol toxic compounds present in OMW. Although no nitrogen compounds were added to the batch experiments, high COD removal rates $(70-80 \%$ at high COD value) were obtained when Gadot or Prigat sludges were used. In accordance with this finding, other researchers have reported that co-digestion of OMW with manure in batch reactors circumvents the need for an external nitrogen source $[44,48,49]$. As expected of the high BOD/COD value of OMW $\left(140,000\right.$ and $27,500 \mathrm{mg} \cdot \mathrm{L}^{-1}$, respectively) compared to the low BOD/COD value of SW $(22,440$ and $17,450 \mathrm{mg} \cdot \mathrm{L}^{-1}$, respectively), the degradation ability of the sludge bacteria for SW when SW was the sole wastewater source, was very high $(85-95 \%$ COD removal rate) for all sludge types tested, even at COD concentrations reaching $17,000-18,000 \mathrm{mg} \cdot \mathrm{mL}^{-1}$. In contrast, COD concentrations as low as $10,000-12,000 \mathrm{mg} \cdot \mathrm{mL}^{-1}$ hindered completely the degradation ability of the bacteria in all sludge types (data not shown). This clearly indicates that the negative effect of OMW:SW mixture on co-digestion is exerted by toxic compounds primarily from OMW, such as the phenolic compounds. The batch experiments presented here clearly show that the co-digestion rate and the accumulated amounts of the biogas are dependent on the initial COD and on the type of the seeded sludge. Since the Gadot and Prigat sludges exhibited the highest COD removal capacity (70-80\% at high COD value), both were selected for further experimentation as the seeded sludges for the UASB reactors.

\subsection{UASB Experiments}

The calculated OLR of each UASB reactor was on average $38 \mathrm{~g} /(\mathrm{L} \cdot \mathrm{d})(\mathrm{COD})$ in the first 60 days and $110 \mathrm{~g} /(\mathrm{L} \cdot \mathrm{d})$ (COD) thereafter. Both reactors were started on a ratio of OMW and SW of 1:2, respectively, and on day 70 the ratio was changed to 1:1.5 for few days (Figures 6 and 7). Such a change caused an immediate drop in the COD removal capacity into ca $70 \%$, therefore the ratio was switched back in both UASB into 1:2 ratio. This indicates that the toxic organic compounds present in OMW begin to affect co-digestion capacity of these sludges at a ratio of 1:1.5 and lower. This is a similar inhibition effect was noticed when the COD level was raised more than $17,250 \mathrm{mg} \cdot \mathrm{L}^{-1}$ in the batch experiments (Figures 4 and 5). However, such detrimental effect was only transient, suggesting that the effect of the inhibitory compounds is reversible and that the co-digestion process operating in the conditions described is stable enough to contain minor inhibitory changes. During 170 days of operation, the COD removal capacity of both UASBs was in the range of $85-95 \%$ (Figures 6 and 7). This is the first published result in which a co-digestion process of OMW with SW results in such extremely high levels of COD removal.

In the last decade, most of the research on OMW treatment has been focused on the use and development of coagulation-flocculation treatments, anaerobic methods and bioreactors such as UASB reactors that can efficiently remove the high organic load and phenolic compounds $[6,19,50,51]$. Co-digestion of OMW and manure in UASB reactors successfully removed $65 \%-75 \%$ of the initial COD load $[44,48,49]$. In one study [44], it was shown that the high content of ammonia in swine manure, together with the contents of other nutrients, made the co-digestion process possible without the external addition of alkalinity and extra nitrogen. Anaerobic digestion of OMW mixed with swine effluents was carried out using up-flow anaerobic filter type reactor, which resulted in the conversion of $70-80 \%$ of the initial COD

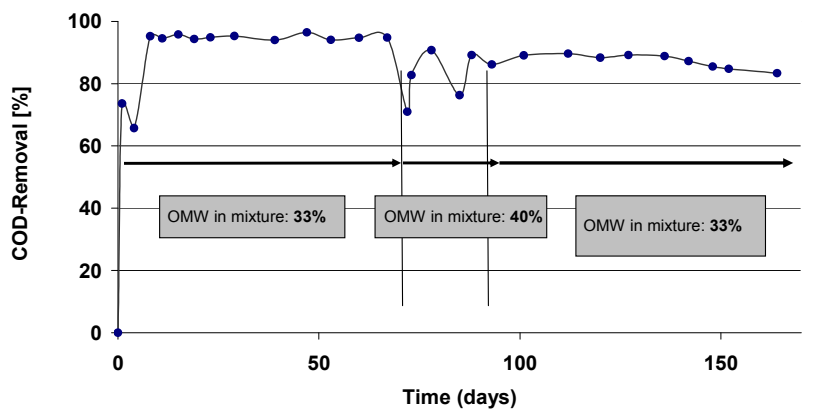

Figure 6. The COD reduction rate over time of OMW: SW co-digestion in UASB system seeded with Prigat sludge.

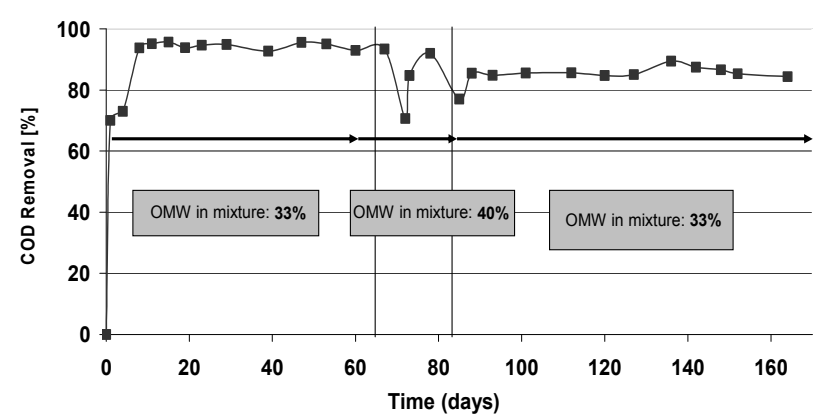

Figure 7. The COD reduction rate over time of OMW: SW co-digestion in UASB system seeded with Gadot sludge. 
(20-60 $\left.\mathrm{kg} \cdot \mathrm{m}^{-3}\right)$, and produced $1-3 \mathrm{~m}^{3} \cdot \mathrm{m}^{-3} \cdot \mathrm{d}^{-1}$ of biogas and a stabilized effluent with neutral/basic $\mathrm{pH}$ [46]. These two F1 and F2 digesters were run for 439 and 473 experimental days, respectively [46]. Our data show that using a UASB reactor seeded with unique sludges, such as Prigat or Gadot, higher COD removal capacities of $85-95 \%$ can be achieved and were rung for 170 days.

A mathematical model was developed to describe anaerobic co-digestion of manure with OMW effluents [49]. Simulation data indicated that lack of ammonia, needed as a nitrogen source for bacterial growth and as an important $\mathrm{pH}$ buffer, could be responsible for the problems encountered when anaerobic degradation of OMW alone was attempted. It was shown that the amount of nitrogen needed to obtain a stable degradation of OMW can be provided by manure during co-digestion of OMW and animal manure [49].

Anaerobic co-digestion of OMW with SW has other advantages over anaerobic digestion of OMW alone, particularly in introducing bacteria capable of phenol biodegradation through the addition of SW. An anaerobic consortium of bacteria containing sulfate-reducing bacteria and acetate-utilizing methanogenic bacteria were isolated from swine manure [52]. This consortium used phenol as its sole source of carbon and converted it to methane and $\mathrm{CO}_{2}$. The metabolic activities of both sulfate-reducing bacteria and the methanogenic bacteria were essential for complete degradation of [52]. Hence, co-digestion may also provide a simple means for reducing the level of phenolic compounds in OMW wastewater. The microbial communities in Prigat and Gadot sludges involved in the processes of biodegradation and biogas production are now under investigation in our lab.

\section{Acknowledgements}

This research was supported by a grant from the National Ministry of Infrastructure, Jerusalem, Israel. Many thanks to Mr. Yacob Haj and Mr. Nidal Masalha, R\&D Galilee Society, Israel for their technical assistance throughout the project.

\section{References}

[1] I. Ballesteros, J. M. Oliva, F. Saez and M. Ballesteros, "Ethanol Production from Lignocellulosic Byproducts of Olive Oil Extraction," Applied Biochemical Biotechnology, Vol. 91-93, No. 1-9, 2001, pp. 237-252.

[2] M. Beccari, F. Bonemazzi, M. Majone and C. Riccardi, "Interactions between Acidogenesis and Methanogenesis in the Anaerobic Treatment of Olive Mill Effluents," Water Research, Vol. 30, No. 1, 1996, pp. 183-189.

[3] I. Sabbah, T. Marsook and S. Basheer, "The Effect of Pretreatment on Anaerobic Activity of Olive Mill Wastewater Using Batch and Continuous Systems," Process Biochemistry, Vol. 39, No. 12, October 2004, pp. 1947-1951.
[4] R. Capasso, G. Cristinzio, A. Evidente and F. Scognamiglio, "Isolation, Spectroscopy and Selective Phytotoxic Effects of Polyphenols from Vegetable Waste Waters," Phytochemistry, Vol. 31, No. 12, December 1992, pp. 4125-4128.

[5] M. Hamdi, "Future Prospects and Constraints of Olive Mill Wastewaters Use and Treatment: A Review," Bioprocess and Biosystems Engineering, Vol. 8, No. 5-6, 1993, pp. 209-214.

[6] M. Hamdi "Anaerobic Digestion of Olive Mill Wastewaters," Process Biochemistry, Vo. 31, No. 2, 1996, pp. 105-110.

[7] M. Bejarano and L. Madrid, "Solubilization of Heavy Metals from a River Sediment by a Residue from Olive Oil Industry," Environmental Technology, Vol. 13, 1992, pp. 979-985.

[8] E. S. Aktas, S. Imre and L. Ersoy, "Characterization and Lime Treatment of Olive Mill Wastewater," Water Research, Vol. 35, No. 9, June 2001, pp. 2336-2340.

[9] J. Beltran-Heredia, J. Torregrosa, J. Garcia, J. R. Dominguez and J. C. Tierno, "Degradation of Olive Mill Wastewater by the Combination of Fenton's Reagent and Ozonation Processes with an Aerobic Biological Treatment," Water Science and Technology, Vol. 44, No. 5, 2001, pp. 103-108.

[10] P. Longhi, B. Vodopivec and G. Fiori, "Electrochemical Treatment of Olive Oil Mill Wastewater," Annali di chimica, Vol. 91, No. 3-4, 2001, pp. 169-174.

[11] A. M. Polcaro, M. Mascia, S. Palmas and A. Vacca, "Electrochemical Oxidation of P-hydroxybenzoic and Protocathecuic Acids at a Dimensional Stable Anode (DSA) in the Presence of NaCl," Annali di chimica, Vol. 92, 2002, pp. 1015-1023, 2002.

[12] S. Khoufi, H. Aouissaoui, M. Penninckx and S. Sayadi, "Application of Electro-Fenton Oxidation for the Detoxification of Olive Mill Wastewater Phenolic Compounds," Water Science and Technology, Vol. 49, No. 4, 2004, pp. 97-102.

[13] R. Borja, A. Martin and A. Garrido, "Anaerobic Digestion of Black-Olive Wastewater," Bioresource Technology, Vol. 45, pp. 27-32, 1993.

[14] G. N. Demirer, T. H. Erguder and E. Guven, "Anaerobic Treatment of Olive Mill Wastes in Batch Digester," Process Biochemistry, Vol. 36, 2000, pp. 243-248.

[15] F. Boubaker and B. C. Ridah, "Anaerobic Co-digestion of Olive Mill Wastewater with Olive Mill Solid Waste in a Tubular Digester at Mesophilic Temperature," Bioresource Technology, Vol. 98, No. 4, 2007, pp. 769-774.

[16] S. Khoufi, F. Aloui and S. Sayadi, "Treatment of Olive Oil Mill Wastewater by Combined Process Electro-Fenton Reaction and Anaerobic Digestion," Water Research, Vol. 40, No. 10, June 2006, pp. 2007-2016.

[17] K. V. Rajeshwari, M. Balakrishnan, A. Kansal, K. Lata and V. V. N. Kishore, "State-of-the-art of Anaerobic Digestion Technology for Industrial Wastewater Treatment," Renewable and Sustainable Energy Reviews, Vol. 4, No. 2, June 2000, pp. 135-156. 
[18] G. Ubay and I. Ozturk, "Anaerobic Treatment of Olive Mill Effluents," Water Science and Technology, Vol. 36, No. 2-3, 1997, pp. 287-294.

[19] R. Andreozzi, G. Longo, M. Majone and G. Modeti, "Integrated Treatment of Olive Oil Mill Effluents (OME): Study of Ozonation Coupled with Anaerobic Digestion," Water Research, Vol. 32, No. 8, August 1998, pp. 2357-2364.

[20] I. W. Koster and A. Cramer, "Inhibition of MethanogeneSis from Acetate in Granular Sludge by Long-Chain Fatty Acids," Applied Environmental Microbiology, Vol. 53, No. 2, February 1987, pp. 403-409.

[21] K. Hanaki, T. Matsuo and M. Nagase, "Mechanism of Inhibition Caused by Long Chain Fatty Acids in Anaerobic Digestion Process," Biotechnology and Bioengineering, Vol. 23, No. 7, 1981, pp. 1591-1610.

[22] F. Raposo, R. Borja, E. Sanchez, M.A. Martin and A. Martin, "Performance and Kinetic Evaluation of the Anaerobic Digestion of Two-Phase Olive Mill Effluents in Reactors with Suspended and Immobilized Biomass," Water Research, Vol. 38, No. 8, April 2004, pp. 2017-2026.

[23] I. Sabbah, A. Yazbak, J. Haj, A. Saliba and S. Basheer, "Biomass Selection for Optimal Anaerobic Treatment of Olive Mill Wastewater," Environmental Technology, Vol. 26, 2005, pp. 47-54.

[24] L. Bertin, S. Berselli, F. Fava, M. Petrangeli-Papini and L. Marchetti, "Anaerobic Digestion of Olive Mill Wastewaters in Biofilm Reactors Packed with Granular Activated Carbon and 'Manville' Silica Beads," Water Research, Vol. 38, No. 14-15, 2004, pp. 3167-3178.

[25] R. Casa, A. D’Annibale, F. Pieruccetti, S. R. Stazi, G. Giovannozzi-Sermanni and B. Lo Casci, "Reduction of the Phenolic Components in Olive-Mill Wastewater by an Enzymatic Treatment and its Impact on Durum Wheat (Triticum durum Desf.) Germinability," Chemosphere, Vol. 50, No. 8, 2003, pp. 959-966.

[26] R. Borja, J. Alba, S. E. Garrido, L. Martinez, M. P. Garcia, M. Monteoliva and A. Ramos-Cormenzana, "Effect of Aerobic Pretreatment with Aspergillus Terreus on the Anaerobic Digestion of Olive-Mill Wastewater," Biotechnology and Applied Biochemistry, Vol. 22, 1995, pp. 233-246.

[27] N. Vassilev, M. Fenice, F. Federici and R. Azcon, "Olive Mill Waste Water Treatment by Immobilized Cells of Aspergillus Niger and its Enrichment with Soluble Phosphate," Process Biochemistry, Vol. 32, 1997, pp. 617-620.

[28] P. Blanquez, G. Caminal, M. Sarra, M. T. Vicent and X. Gabarrell, "Olive Oil Mill Waste Waters Decoloration and Detoxification in a Bioreactor by the White Rot Fungus Phanerochaete Flavido-Alba," Biotechnology Progress, Vol. 18, 2002, pp. 660-662.

[29] M. S. Fountoulakis, S. N. Dokianakis, M. E. Kornaros, G. G. Aggelis and G. Lyberatos, "Removal of Phenolics in Olive Mill Wastewaters Using the White-Rot Fungus Pleurotus Ostreatus," Water Research, Vol. 36, 2002, pp. 4735-4744.

[30] A. Tsioulpas, D. Dimou, D. Iconomou and G. Aggelis, "Phenolic Removal in Olive Oil Mill Wastewater by Strains of Pleurotus Spp. in Respect to their Phenol Oxi- dase (laccase) Activity," Bioresource Technology, Vol. 84, 2002, pp. 251-257.

[31] G. Aggelis, D. Iconomou, M. Christou, D. Bokas, S. Kotzailias, G. Christou, V. Tsagou and S. Papanikolao, "Phenolic removal in a Model Olive Oil Mill Wastewater Using Pleurotus Ostreatus in Bioreactor Cultures and Biological Evaluation of the Process," Water Research, Vol. 37, 2003, pp. 3897-3904.

[32] A. Dhouib, M. Ellouz, F. Aloui and S. Sayadi, "Effect of Bioaugmentation of Activated Sludge with White-Rot Fungi on Olive Mill Wastewater Detoxification," Letters of Applied Microbiology, Vol. 42, 2006, pp. 405-411.

[33] G. Pinto, A. Pollio, L. Previtera, M. Stanzione and F. Temussi, "Removal of Low Molecular Weight Phenols from Olive Oil Mill Wastewater Using Microalgae," Biotechnolgy Letters, Vol. 25, 2003, pp. 1657-1659.

[34] F. Alatriste-Mondragon, P. Samar, H. H. Cox, B. K. Ahring and R. Iranpour, "Anaerobic Co-digestion of Municipal, Farm, and Industrial Organic Wastes: A Survey of Recent Literature," Water Environmental Research, Vol. 78, 2006, pp. 607-636.

[35] B. S. Magbanua, T. T. Adams and P. Johnston, "Anaerobic Co-digestion of Hog and Poultry Waste," Bioresource Technology, Vol. 76, 2001, pp. 165-168.

[36] P. Kaparaju, S. Luostarinen, E. Kalmari, J. Kalmari and J. Rintala, "Co-digestion of Energy Crops and Industrial Confectionery Byproducts with Cow Manure: Batch-Scale and Farm-Scale Evaluation," Water Science and Technology, Vol. 45, 2002, pp. 275-280.

[37] H. N. Chinivasagam, R. J. Thomas, K. Casey, E. McGahan, E. A. Gardner, M. Rafiee and P. J. Blackall, "Microbiological Status of Piggery Effluent from 13 Piggeries in the South East Queensland Region of Australia," Journal of Applied Microbiology, Vol. 97, No. 5, 2004, pp. 883-891.

[38] I. Phillips, M. Casewell, T. Cox, B. De Groot, C. Friis, R. Jones, C. Nightingale, R. Preston and J. Waddell, "Does the Use of Antibiotics in Food Animals Pose a Risk to Human Health? A Critical Review of Published Data," Journal of Antimicrobial Chemotherapy, Vol. 53, 2004, pp. 28-52.

[39] N. T. Malintan and M. A. Mohd, "Determination of Sulfonamides in Selected Malaysian Swine Wastewater by High-Performance Liquid Chromatography," Journal of Chromatogrphy, Vol. 1127, No. 1-2, September 2006, pp. 154-160.

[40] R. F. Spalding and M. E. Exner, "Occurrence of Nitrate in Groundwater: A Review," Journal of Environmental Quality, Vol. 22, 1993, pp. 392-402.

[41] T. Y. Guan and R. A. Holley, "Pathogen Survival in Swine Manure Environments and Transmission of $\mathrm{Hu}-$ man Enteric Illness: A Review," Journal of Environmental Quality, Vol. 32, 2003, pp. 383-392.

[42] H. N. Gavala, I. V. Skiadas, N. A. Bozinisn and G. Lyberatos, "Anaerobic Co-digestion of Agricultural Industries Wastewaters," Water Science and Technology, Vol. 34, 1996, pp. 67-75.

[43] G. Lyberatos, H. N. Gavala and A. Stamatelatou, "An Integrated Approach for Management of Agricultural In- 
dustries Wastewaters," Nonlinear Analysis, Vol. 30, 1997 , pp. 2341-2351.

[44] I. Angelidaki, B. K. Ahring, H. Deng and J. E. Schmidt, "Anaerobic Digestion of Olive Oil Mill Effluents Together with Swine Manure in UASB Reactors," Water Science and Technology, Vol. 45, 2002, pp. 213-218.

[45] A. S. Bal and N. N. Dhagat, "Upflow Anaerobic Sludge Blanket Reactor: A Review," Indian Journal of Environmental Health, Vol. 43, 2001, pp. 1-82.

[46] I. P. Marques, "Anaerobic Digestion Treatment of Olive Mill Wastewater for Effluent Reuse in Irrigation," Desalination, Vol. 137, 2001, pp. 233-239.

[47] M. C. Rand, A. E. Greenberg and M. J. Taras, "Standard Methods For the Examination of Water and Wastewater," American Public Health Association, Washington, DC, 1975.

[48] I. Angelidaki and B. K. Ahring, "Co-digestion of Oil Mill Wastewaters Together with Manure, Household Waste or
Sewage Sludge,” Biodegradation, Vol. 8, 1997, pp. 221-226.

[49] Angelidaki and B. K. Ahring, "Modeling Anaerobic Co-digestion of Manure with Olive Oil Mill Effluent," Water Science and Technology, Vol. 36, 1997, pp. 263270.

[50] M. Beccari, G. Carucci, A. M. Lanz, M. Majone and M. Petrangeli-Papini, "Removal of Molecular Weight Fractions of COD and Phenolic Compounds in an Integrated Treatment of Olive Oil Mill Effluents," Biodegradation, Vol. 13, No. 6, December 2002, pp. 401-410.

[51] M. Beccari, G. Carucci, M. Majone and L. Torrisi, "Role of Lipids and Phenolic Compounds in the Anaerobic Treatment of Olive Oil Mill Effluents," Environmental Technology, Vol. 20, 1999, pp. 105-110.

[52] R. Boopathy, "Anaerobic Phenol Degradation by Microorganisms of Swine Manure," Current Microbiology, Vol. 35, 1997, pp. 64-67. 